\title{
Forms of Instagram Social Media Communication in Promoting Lampung Province Tourism
}

\author{
Rosy Febriani Daud ${ }^{\mathrm{a}, 1^{*}}$, Deddy Aprilani ${ }^{\mathrm{b}, 2}$, Ade Rama Dhani Kusuma ${ }^{\mathrm{c}, 3}$ \\ ${ }^{a, c}$ Muhammadiyah University Kotabumi, ${ }^{b}$ University of Lampung \\ Email: 1'rosydaud@gmail.com, ${ }^{2}$ pesandeddy@gmail.com, ${ }^{3}$ aderama0406@gmail.com \\ *corresponding author
}

Keywords:

Social Media, Promotion, Tourism

\begin{abstract}
This study aimed to determine the forms of promotion on social media Instagram by the tourism office to promote tourism in Lampung Province. To find out the obstacles experienced by the Lampung Province tourism office in promoting tourism in Lampung Province, to determine the level of success of the tourism office in conducting tourism promotion in Lampung Province using social media Instagram. The method used in this research is the descriptive qualitative method. This qualitative research is descriptive, using secondary data as a reference. Secondary data collection techniques are carried out using literature study techniques, including literature data in journals, books, articles, and news related to research. Researchers found that a form of promotion is advertising, sale promotion, publicity, and promotion through social media, especially Instagram, which effectively stimulates attention. However, Instagram is still not practical at the stages of interest, desire, and action. Promotion through Instagram creates trust for consumers because there are many user testimonials and comments for users to find out more information. Images with HD features look attractive, and the captions accompanying images or video posts also add to the appeal. The obstacles are external and internal. The level of success, seen from the large number of tourists who come and can be visited from how many likes the community gives, or how many impressions the community leaves and the many followers on the account, the success rate of promotion using social media is flourishing.
\end{abstract}

\section{INTRODUCTION}

Media is one element of communication used to produce, reproduce, process, and convey information. It can be said. A communication medium is an intermediary in obtaining information from the communicator to the communicant, aiming to disseminate information or messages efficiently. Social media is digital media or the internet that has potential as a medium for community empowerment. Empowerment can make social media a medium for promoting products or services: tourism products. To a lesser extent, social media has shifted the trend of tourism consumption. In the past, maybe tourism was only a tertiary need. Still, tourism has gone slightly for most communities to become a secondary need even though some groups have made it a primary requirement. Previously, the tourism board used several methods to promote tourism, such as using promotions on TV, advertisements, brochures, and exhibitions.

The use of technology to search for information is now facilitated by social media that allows interactive communication or dialogue. Technological developments also will enable the delivery of exciting content in text, images, audio, and video to provide transparent information about the products and services offered. Not to mention social media is also widely used by the tourism industry.

The potential of social media as a means of interactive promotion for Indonesian tourism is an exciting research topic and is very much needed to improve the tourism industry. Social media is one of the developments of the internet. 
Having a high-quality camera on a smartphone makes many people have fun new activities. People will easily take pictures wherever and whenever. After that, it is uploaded to social media. The types of social media commonly used include Facebook, Twitter, Path, and Instagram. Instagram is a photo-sharing application that allows users to take photos, apply digital filters, and share them to various social networking services, according to Prihatiningsih (Prihatiningsih, 2017).

Social media is currently developing as a means of interaction for various groups around the world. This development was then, of course, immediately used as promotional media, which was considered adequate. In the book Socialnomics: How Social Media Transforms the Way We Live and Do Business in Qualman (E, 2013), Chris Anderson. The broadcast can bring one show to millions of people with unmatchable efficiency. Nevertheless, it can not do the opposite - get a million plays to one person each. However, that is what the Internet does so well. The economics of the broadcast era required hit shows — big buckets — to catch huge audiences.

Serving the same stream simultaneously at the same time is hugely expensive and wasteful for a distribution network optimized for point-to-point communications. Increasingly, the mass market is turning into a mass of niches. Social media is a development in disseminating information. In the past, media technology conveyed messages to millions of people efficiently, such as through television or newspapers. The weakness is that delivering messages to millions of people is expensive and not necessarily directed at the desired target. Media users also become passive parties by only accepting all the information provided without being able to choose.

In the big concept of marketing, especially tourism products, social media occupies a determinant factor in the tourism marketing mix, namely the promotion sub-mix. Which is based on social media has a content of communication and product persuasion to prospective tourists. Promotion means activities that communicate the merits of the product and persuade target customers to buy it. It means that promotion is an activity to display products and persuade consumers to purchase the products offered, such as social media.

In traveling, there are always push and pull factors for someone to take a tour, with the driving factors are generally social-psychological or being person-specific motivation and pullers, which are destination-specific attributes. In more detail about these pushes and pull, Richardson and Fluker explain factors in the book Sociology of Tourism (Pitana, 2005). Push factors are all the economic, social, demographic, technological, and political forces that stimulate demand for tourism by 'pushing' consumers away from their usual residence. These are the dominant factors when people decide to 'get away from it all, but are vague about where they want to go.

From the quote above, it is concluded that interaction via social media can be one of the driving factors for someone to take a tour. Facebook, Twitter, or Instagram are part of the power of technology that can provide a stimulus for consumers by driving them to travel. The stimulus given is in the form of media to convey tourism information.

The number of people who have started ordering online can make the tourism industry more prosperous and efficient in running its business and advancing its tourism destinations. Online technology can communicate, inform, negotiate, and reduce communication gaps without being hindered by distance and time. It was creating a new structure for the development and operation of tourism (Hasan, 2015). From this phenomenon, it can be seen that the fastest and most reliable way for tourists to reach tourist attractions is through the internet.

Tourism sector importance is described above for state revenues and as a consumer of tourism or tourists for the movement of the tourism industry in Indonesia. There is an increasing demand for the provision of information about digital tourism or E-Tourism. In the form of social media and managed voluntarily and individually. Lampung Province has felt the impact of digitizing tourism information. E-Tourism is taken from the word Electronic Tourism, which integrates the development of ICT (Information and Communication Technology) with the tourism industry. Caribbean Tourism Organization defines e-Tourism as a dynamic interaction between Information and Communication Technologies (ICTs) and existing Tourism. Each transforms the other ICTs are applied to tourism processes to maximize organizational efficiency and effectiveness. Tourism brings together Business Management, Information, and Communication. The concept of e-Tourism in question is the use of information and communication technology to increase efficiency in the tourism sector, provide various tourism services to customers, and make the implementation of tourism marketing more straightforward in Telematics (Arsul, Arie S.M. Lumenta, 2015).

Lampung Province has a top priority in the development of the tourism industry. Lampung Province also has natural beauty with various tourist objects known as Gurilaps (mountains, forests, sea, beaches, and lakes), diverse traditional arts and cultures, and local customs packaged into tourism commodities sold locally, nationally, and internationally. The Lampung board should adequately communicate the tourism potential of Lampung Province to potential tourists by increasing E-Tourism. Lampung Province has been transformed into a prime tourist destination in the eyes of domestic tourists. The transformation is adapted to the characteristics of tourists who like things that smell of self-existence, one of which is by uploading photos on social media. Lampung Province has beautiful photo spots on its tourist destinations so that it is considered capable of fulfilling the desires of tourists to show their existence. Various social media are used by tourists, such as Facebook, Instagram, Twitter, or blogs. In this study, the social media explored was more specifically for 
Instagram because it is very close to everyday life. After all, it has five roles in shaping teenage personalities; (1) Instagram acts as a medium of information about the people around them. (2) Instagram acts as a medium for developing personal and spiritual interests for the community. (3) Instagram plays a role as a medium to entertain ourselves. (4) Instagram acts as a medium to express emotions for tourists. (5) Instagram plays a role in forming a new self-image for the community.

Based on the formulation of the problems described above, the objectives of this study are; (1) To find out the forms of promotion on social media Instagram by the tourism office as a means of promotion for tourism in Lampung Province. (2) To find out the obstacles experienced by the Lampung Province tourism office in promoting tourism in Lampung Province. (3) To determine the level of success of the tourism office in promoting tourism in Lampung Province by using social media Instagram.

\section{THEORETICAL FRAMEWORK}

\section{A. Social Media}

The term social media is composed of two words, media and social. The media is defined as a communication tool, while the word social is a social fact that every individual takes actions that contribute to society, according to Laughey (2007) in Mulawarman (2017).

Social media is online media that users from all walks of life and are elementary to use. Social media is a place to share information and create Vlog videos, social networks, Wikipedia, forums, and other virtual worlds. Andreas Kaplan and Michael Haenlein define social media as a set of internet-based applications are built on communication technology developments that create communication tools and exchange user-generated content (Kaplan, 2010: 59). Sites in this social network also mediate users to connect to the internet by creating personal information to communicate with other users. Personal information can be in photos, sending videos, making voice calls, and video calls, such as Whatsapp, Facebook, Twitter, Instagram, Youtube, and many more.

The dissemination of information on social media is divided into two types, namely through content and tools. Continuous developments in social media can change people's behavior patterns in seeking and sharing information. However, social media can also allow the emergence of uncertainty in knowledge and errors in the use of social media (Hajar, Herni Wisnumurti, 2020). It will apply differently to each user, depending on the user's ability to use social media. Moreover, their response to the information was obtained reasonably and ethically.

Social media has a vital role in human life. In daily activities, of course, everyone uses social media to obtain or seek information, ranging from places, food, scholarships, politics, and many more. Then as a place to establish friendship, former friends who lost contact can finally meet through social media, and even though we are far apart, we can still communicate intensely (Rahmadi, 2016). The role of social media today is an information seeker and widely as a branding activity. In a general sense, Branding is a collection of communication activities carried out by a company so that the brand (brand) offered is known and has its value in society.

\section{B. Promotion}

Promotion is an element used to inform and persuade the market about new products or services through advertising, personal selling, sales promotions, and publications (Hedynata, 2016 \& Kotler and Armstrong, 2012).

Promotion is a form of marketing communication. Particularly, marketing activities seek to disseminate information, influence or persuade and remind the company's target market and its products to be willing to accept, buy, and be loyal to the products offered by the company concerned (Suryadana, 2015). Promotion is a tool service organizations can use to communicate with their target market (Wandikbo, 2013).

Marketing communication is marketing activities that seek to disseminate information, influence or persuade, and remind the company's target market and its products to be willing to accept, buy, and be loyal to the products offered by the company concerned (Tjiptono, 2015).

According to Tasruddin (2015), in essence, the promotion strategy is part of the marketing strategy, so it needs to be done by implementing integrated marketing communications (KPT), which then automatically creates a promotion mix atmosphere.

\section{Tourism}

Tourism is a term given to a tourist who is traveling far from his area to another area. In other words, tourism can also be said as an activity that occurs when a visitor makes a trip (Permatasari, 2017). Tourism can also be interpreted as an activity or an object related to natural beauty, including tourist objects and tourist attractions, and tourism businesses.

Tourism is an excursion or part of the activity carried out voluntarily and temporarily to enjoy tourist objects and attractions. Tourism (tourism) is a trip carried out for a while, which is held from one place to another, with the intention not to earn a living in the place visited, but solely to enjoy the trip, for sightseeing and recreation or to fulfill various wishes. 
The development of tourism studies from a socio-cultural aspect is getting more attention. Tourism brings a series of positive and negative impacts, which humans directly feel like the central factor. According to Dogan, tourism's economic, social, and cultural effects vary widely from region to region. The nature of the impact depends on the following factors (Hadiwijoyo, 2012); (1) Types of tourists who visit. (2) The receiving community's social, economic, and cultural characteristics include social stratification, economic inequality, and existing social relations. (3) The type of tourism being developed, whether closed or open tourism. (4) The level of institutionalization of tourism development.

Tourism can be widely used as a modern business, where modern tourism is one of the promising business products. All tourism products are designed as business products, ranging from destinations, creative economy, transportation, hospitality, recreational venues, and other exciting and impressive things, of course, to be things worth seeing, visiting, and feeling.

\section{Teori Uses And Gratification}

Seeking Information and Uses and Gratification are theories that outline media understanding and media's impact on society. Social media, in general, includes five things that are given satisfaction, (1) Cognitive information, knowledge, and understanding. (2) Affective emotional experience, fun or aesthetic. (3) Personal integrity increases credibility, confidence, and status. (4) Social integration improves relationships with family, friends, and others. (5) Release of tension: escape and diversion (Morissan, 2013).

Social media acts as the satisfaction of social needs, which is clear evidence of a connection with the two theories above. According to Wilson, information-seeking behavior is a micro-level search behavior shown by a person when interacting with all types of information systems. Information search is highly influenced by the information needs desired by the user. The higher the need for the information he wants, the higher the information search performed by library users. The statement is also supported by Maslow, which is the need for self-actualization. In this case, information is related to the desire for self-fulfillment (Uno, 2011).

In general, information can be used to make decisions to achieve goals (Rachmanto, 2013). The value of information will be different according to its purpose. The purpose of the information generated by an information system is to provide information to assist management decision-making, assist officers in carrying out day-to-day operations of the company, and provide appropriate information to parties outside the company who need it.

Information is processing data in a direction that is more beneficial for its users. Knowledge is replaced by accounts containing information based on specific news, chatting and face-to-face activities are replaced with chat activities, which almost all social media have this feature, face-to-face chats can also be replaced with video calls and many others.

Social media fulfills the needs and provides modern and practical satisfaction to its users, and this is because social media can cover everything that other mass media can do. Thereby creating solid relationships with social media users is essential.

The human needs for media are influenced by the social environment, group affiliations, and personality traits. Human needs related to media are created. It may include cognitive, affective, integrative personalities and social and tension-releasing. Audience needs are; (1) Cognitive needs, namely related to confirmation of information about understanding and the environment. This need is based on a desire to understand and control the setting and satisfy our curiosity. (2) Affective needs, which are related to affirming experiences that are aesthetically pleasing to emotion. This need refers to activities or anything related to pleasant behavior. (3) In an integrative way, personal needs are related to credibility, trust, stability, and individual status obtained from desire and self-esteem. (4) Social needs in an integrative manner related to strengthening contact with family, friends, and the world. It is based on the desire to realize things. (5) The need for tension release is a need related to efforts to avoid pressure, tension, and a desire for diversity (Effendy, 2013)

A person's needs or uses and gratifications theory and approach do not cover or represent the entire communication process because most of the audience's behavior is only explained through various needs (needs) and interests (media messages). The uses and gratifications approach describes the acceptance process in mass communication and explains media use by individuals or individual aggregations (Septianie, 2013).

The uses and gratifications theory has five basic assumptions; (1) The audience is considered active, and mass media is assumed to have a purpose. (2) More initiatives related to satisfying the needs and selecting the media to lie with audience members in the mass communication process. (3) The mass media competes with other sources to satisfy their needs. (4) Data provided by audience members can infer the purpose of using mass media. (5) The assessment of the cultural meaning of the mass media must be suspended before researching the audience orientation (Rakhmat, 2010)

In this study, the relationship between the user and gratifications theory approach with the topic of this study leads to attention to the use of media content to obtain gratification for the needs of tourists or the community, which in this theory is an active audience, intentionally using Instagram as a means of communication. in meeting their needs. The usability and satisfaction approach questions what people do with the media, namely using Instagram media to satisfy their needs. The theory of usefulness and satisfaction is more on a human approach in viewing media. Lampung Province 
has autonomy and has the authority to treat Instagram as a tourism promotion tool. The researcher believes that there is not only one way for Lampung Province to use the media.

On the other hand, Lampung Province believes that there are many reasons for people to use Instagram. Lampung Province has media and the freedom to decide how within which media. Lampung Province uses Instagram media and how Instagram media will impact tourism promotion in the Lampung Province area. It can be said that the reason why Lampung Province uses Instagram media is the social-psychological condition of the community, which is perceived as a problem by Lampung Province in promoting tourism areas. The community uses Instagram media to overcome these problems. Uses and gratifications distinguish the notion of activity or activity with activity or activity to understand better the community, which is meant by activity refers to what is done by media consumers, in this case, the community. Meanwhile, what is meant by activeness refers to the freedom possessed by the community and autonomy in mass communication situations. Activities are relative and vary for each individual.

\section{RESEARCH METHODS}

The method used in this research is the descriptive-qualitative method. This qualitative research is descriptive by using secondary data as a reference. Qualitative research methods are studies used to examine natural objects where the researcher is the key instrument, data collection techniques are combined, data analysis is inductive, and qualitative research results emphasize meaning than generalization (Prasanti, (2018).

Informants Qualitative research is not intended to make generalizations from a research result. Research subjects that have been reflected in the research focus are not determined intentionally. Research subjects become informants who will provide various information needed during the research process. The informants of this research include three kinds (Sondak, 2019), namely: 1. Key informants, namely those who know and have the various basic information needed in research. 2. The primary informants, namely those who are directly involved in the social interactions studied. 3. Additional informants, namely those who can provide information even though they are not directly involved in the social interactions studied.

Researchers used a purposive sampling technique. Purposive sampling is a sampling technique of data sources with specific considerations (Daud, 2020). For example, this particular development is the person who is considered to know what we expect, or maybe he is the ruler to make it easier for researchers to explore the object or situation under study. Alternatively, in other words, sampling is taken based on research needs.

Secondary data are data sources that do not directly provide data to data collectors (Pratiwi, 2017). Examples such as from other people or documents. Secondary data is data that supports the needs of primary data. The secondary data used in this research are journal documents.

\section{DISCUSSION}

\section{A. Forms of Promotion on Social Media used by the Lampung Province Tourism Office in Promoting Tourism in Lampung Province.}

The presence of the Internet changes everything, including in communication, such as the practice of Public Relations. Internet is a technological tool but more important as a mechanism that enables a communication revolution that drives significant changes in the dynamics of society. The Internet is changing every discipline related to the exchange of information. Each level of the process of exchanging information and outcomes is based on responses and reactions to information. Social media has revolutionized corporate communications. Social media marketing allows companies to communicate directly with their consumers, which shifts both companies and consumers. Social media marketing is a general term that includes social media for sales, marketing, customer service, and public relations, indicating the convergence of separate traditional corporate departments.

Social Media will continue to evolve and change, and corporate communication practices will change. Social media has proven to be a tool for industry, and the future holds a broader role and implementation of such tools. The advent of social media has resulted in the evolution of corporate communications.

The public relations industry has overgrown from changing traditional practices to accommodate constant change and new tools, create opportunities for conversation, and campaigns for corporate profits. In carrying out promotions using social media Instagram, the Tourism Office has the right marketing management communication strategy to help penetrate the market through information. In marketing communication, marketing is how all communication activities used to market products generate profits. In this case, the profit expected by the tourism office is an increase in tourists who come to Lampung Province.

So it is almost confident that all of these things that use a marketing communication strategy will reap the maximum results as expected. Things that are done as all forms of promotion are one of persuasive communication so that how people are interested in what we share on social media. 

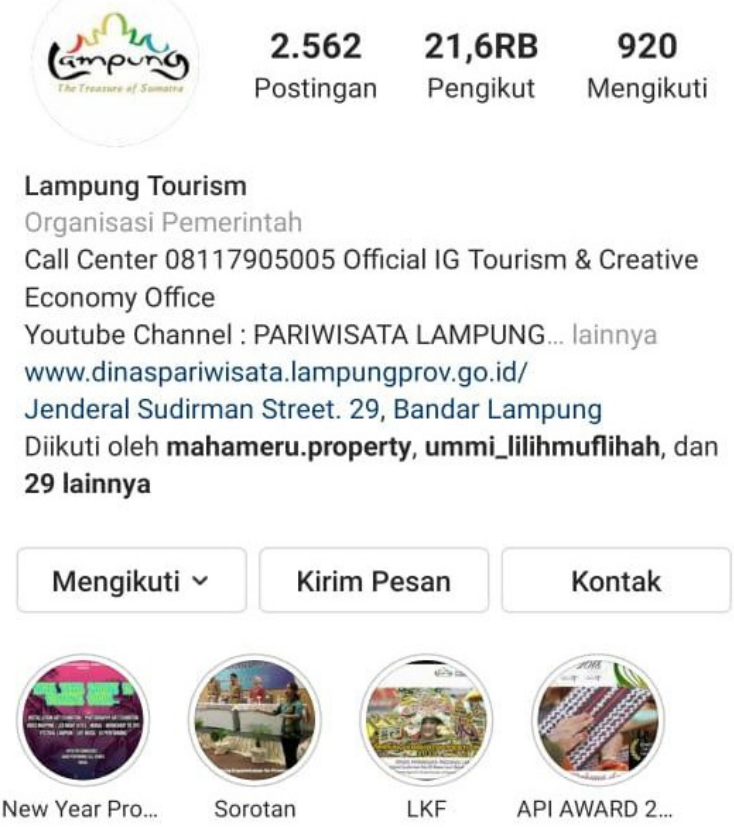

囲

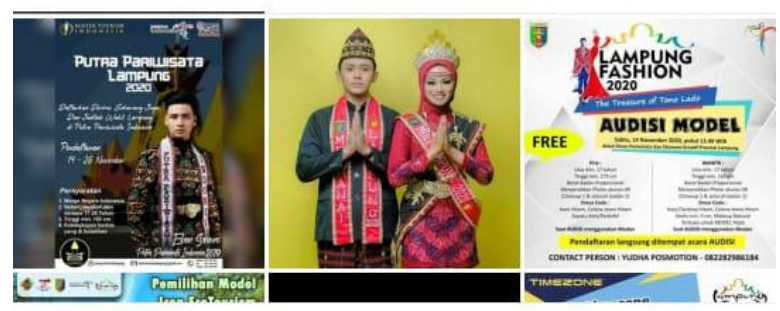

Image1. Instagram Account of Lampung Province Tourism Office, 2020

The interview results were related to the forms of promotion on social media used by the Lampung Provincial Tourism Office. Dr. Edarwan said, SE, M.Si, as the head of the Lampung Province Tourism Office, explained that his goal for the tourism office is to bring in as many people as possible. So that the tourism office uses promotion using social media, namely advertising and publicity. With the existence of social media, which has always been part of the daily activities of almost all people, doing advertisements and hype on social media is the right thing. Advertising and publicity are one form of promotion used by the Lampung Province tourism office.

The role of advertising in service marketing is to build awareness of potential buyers or clients or targets for the services or goods offered, increase consumer knowledge, persuade potential buyers to buy, use these services, and differentiate services from one company to others. In this case, the author can see that indeed the form of promotion, namely advertising dominates as one of the tourism promotions of Lampung Province using social media.

Using social media to create advertisements makes it possible to better introduce the tourism sector in Lampung Province to the broader community. The statement of one of the employees in the promotion admin field, Mrs. Tati Sulastri, explained that the use of social media as promotional media is something that is very much needed in this millennial era, as the era of social media has become something close to the community, so it is the right thing to use social media. As a promotional tool in the form of advertisements and publishing on social media.

Social media is used as a promotional tool to advertise a product or service to the general public or the public, namely the community. Besides that, it is indispensable to increase public interest in tourism in Lampung Province. Besides being cheap for access costs, social media has also become a favorite media for the community. It is what the Tourism Office sees as an activist in the tourism sector. Instagram is the social media of choice to promote tourism in Lampung Province.

\section{B. The barriers of Lampung Province Tourism Office in promoting tourism using social media.}

Social media was created for social interaction and allows for faster, cheaper communication anytime and anywhere. On the one hand, media helps communicate with other people, but on the other hand, because it is connected 
virtually at all times with the latest status of social media sites, it causes social media users to not communicate with each other in the real world.

The use of social media as a means of promoting tourism is certainly not an easy thing. Many unwanted things often happen, which result in hindering the performance of using social media. Barriers that occur in using social media as a means of promotion can affect performance results and the results of all promotions carried out.

Regarding the obstacles in using social media as a means of promotion, Mr. Budiman Sujatmiko mentioned that the obstacles that often occur are usually internal and external, which means that the obstacles that occur from within are from the team itself. For example, it is crucial to care about the importance of tourism in a city in mental terms. Lampung. The barrier from the outside is that this usually occurs in our society, which means that sometimes our society makes content posts that are contrary to what we post in society, so that people's views do not fully trust us as an institution responsible for tourism. For example, when posting good things about tourism in Lampung Province, people post bad thin like floods, traffic jams, and many others. It has had a massive impact on the increase in tourists in Lampung Province and demonstrations that students often carry out with our institutions regarding tourism funds. The tourism office only gets 30 billion every year. Furthermore, that is used to create significant events so we actually cannot move.

In line with what was conveyed by the previous source, Mrs. Tati Sulastri, the social media admin, said the same thing. Obstacles or obstacles in using social media as one of the promotional media cannot be avoided from obstacles, such as people who post things contrary to the tourism office and negative things on social media about Lampung Province. Other obstacles also come from us as people who run social media. For example, our mentality must be prepared to continue active on social media, and we also have to become media literate people.

From the interview above, it can be concluded that the obstacles that occur can be categorized into two obstacles, namely internal and external obstacles, namely internal obstacles and external obstacles. Internal obstacles are from workers in the tourism office who experience problems, such as mental health, that must be improved. Then the barrier from outside is in the form of public posts on social media, which are inversely proportional to the Tourism Office. People, especially in Lampung Province, are not all aware of or sensitive to their environment, so negative things are spread on social media instead of the Tourism Office, which posts about the beauty of tourism itself. It will affect social media content and quality as a means of promoting tourism in Lampung Province.

\section{The Level of Success of the Lampung Province Tourism Office in Promoting Tourism in Lampung Province Using Social Media.}

The successful use of social media as a means of promotion is undoubted to be expected. Often, managing social media is considered trivial so that ultimately no one is explicitly handling it. If this problem is ignored, do not be surprised if, in the end, there are many suboptimal results in running social media marketing or social media as a means of doing promotion.

When doing promotions about the products offered or shown, choose the right time. Try not to update the status that contains product promotions because this can make followers feel bored over time and then leave. Lampung city tourism office also definitely offers the best results.

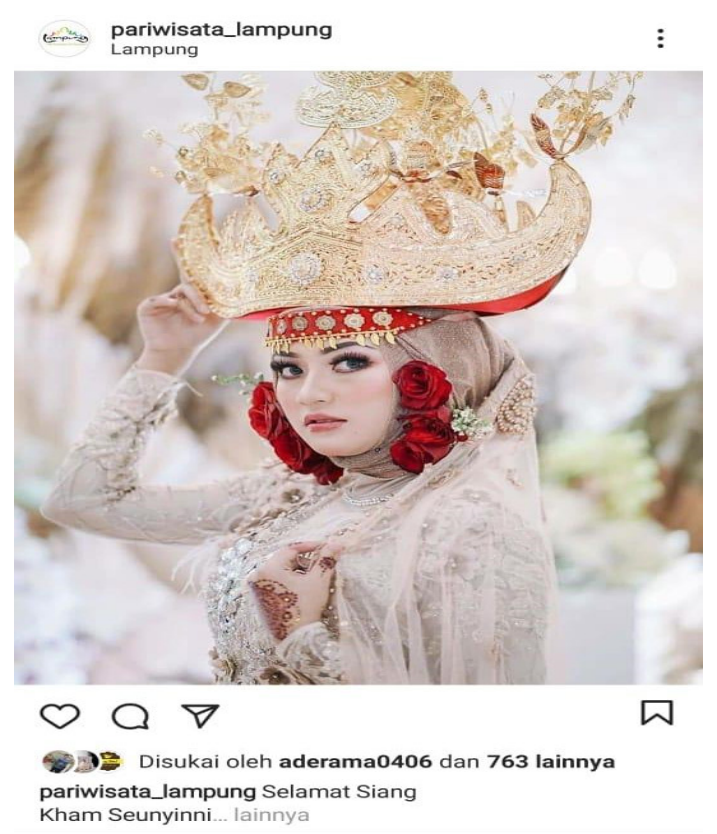

Image2. Feed content of Lampung Province Tourism Office Instagram Account, 2020 
The interview results with the Head of the Lampung Province Tourism Office, Dr. Edarwan, S. E, M.Si, conveyed how the successful use of social media as a means of tourism promotion in Lampung Province. The achievement in social media campaigns can be seen clearly how many followers the account has, meaning that the more followers on the account, the success rate of promotion using social media is flourishing. Thriving response the community gave many responses seen from the comments and suggestions given by the community. Our target is that the Tourism Office wants to increase the 10 thousand followers on the IG account and it can also be seen from the reports that hotels are always full at the end of the week which is also one of the successes of our tourism office to bring in as many people as possible.

Supported by almost the same answer, Ridho Alamsyah stated that social media is a transparent media, spreads quickly, has a trail that is difficult to leave. It means that social media is open media, so the effectiveness of using social media is easy for us to know. With so many thumbs that the community gives, then comments and shares to other accounts, people empathize with what is in the posts we share.

In line with the statements of the two speakers, Tati Sulastri also said that their success in promoting in social media could be seen from how many followers have increased, then the likes given by the community. Furthermore, they received advice from the public on social media, so this can be said to be their success.

It can be concluded that the success of using social media as a means of promotion can be seen from how many likes the community has given, or how many impressions are left by the public and many followers on these accounts, the success rate of promotion using social media is flourishing. Promotion through Instagram creates trust for consumers because there are many user testimonials and comments for users to find out more information. Images with HD features appear dashing and beautiful on the timeline, giving rise to high confidence and interest that the company or the account owner is the one who makes it bona fide and the products are of good quality.

The function and role of Instagram social media change the way a person communicates, which was initially one and two-way, now in all directions. It can also be an important channel for retailers to connect with consumer opinion and get the general public to solve problems regarding new products and services. Promotion through Instagram effectively stimulates attention, but Instagram is still not practical at interest, desire, and action stages. Instagram media is very suitable for attracting the attention of Instagram users so that Instagram users know various information, especially regarding the promotion of a product, but for the purchase, action is still unlikely. The informed promotion.

\section{CONCLUSION}

The conclusion drawn from this research is that the form of tourism promotion in Lampung Province uses social media, namely Instagram. In carrying out promotions using Instagram social media, the Tourism Office has the right marketing management communication strategy to help market penetration through information. In marketing communications, marketing is how all communication activities used to market products generate profits. In this case, the profit expected by the tourism office is an increase in tourists coming to Lampung Province. In this case, the author can see that promotion, namely advertising, dominates as one of the tourism promotions in Lampung Province by using social media. The obstacles obtained from this research are that the obstacles that occur can be categorized into two obstacles, namely internal barriers and external obstacles, namely internal barriers and external barriers. Internal constraints come from workers in the tourism office who experience problems, such as mental health, that must be improved. Then external obstacles are in the form of public posts on social media, which are inversely proportional to the Tourism Office. People, especially in Lampung Province, are not all aware or sensitive to their environment, so negative things are scattered on social media, unlike the Tourism Office, which of course, posts about the beauty of tourism itself. It will affect social media content and quality as a means of tourism promotion in Lampung Province. The success of using social media as a means of promotion can be seen from how many likes the community gives, or how many impressions are left by the public, and the number of followers on the account, the success rate of promotion using social media is flourishing.

\section{BIBLIOGRAPHY}

[1] Amstrong, Gary \& Philip, K. (2012). Dasar-Dasar Pemasaran. Jilid I, Alih Bahasa Alexander Sindoro dan Benyamin Molan. Prenhalindo.

[2] Arsul, Arie S.M. Lumenta, B. A. S. (2015). NE-Tourism Kabupaten Pulau Morotai. Jurnal Teknik Elektro Dan Komputer, 4, 71-78.

[3] Daud, Rosy Febriani, K. (2020). Peran Marketing Public Relations (MPR) Dalam Membangun Brand Image Warunk Upnormal Di Bandung. KOMUNIKASIANA (Journal of Communication Studies.

[4] E, Q. (2013). Socialnomics: Bagaimana media sosial mengubah cara kita hidup dan berbisnis. John Wiley \& Sons, Inc.

[5] Effendy, O. U. (2013). Ilmu Komunikasi Teori dan Praktek. PT Remaja Rosdakarya.

[6] Hadiwijoyo, S. S. (2012). Perencanaan Pariwisata Perdesaan berbasis Masyarakat. Graha Ilmu. 
[7] Hajar, Herni Wisnumurti, M. A. R. (2020). Peran Media Sosial Pada Perilaku Informasi Mahasiswa Dalam Menyikapi Isu Kesehatan. Jurnal Ilmu Informasi, Perpustakaan, Dan Kearsipan, 22, 103-115.

[8] Hamzah B. Uno. (2011). Teori Motivasi dan Pengukurannya: Analisis Dalam Bidang Pendidikan. Bumi Literasi.

[9] Hasan, A. (2015). Pemasaran Pariwisata. CAPS (Pusat Layanan Penerbitan Akademik).

[10] Hedynata, Marceline Livia, W. E. D. R. (2016). Strategi Promosi Dalam Meningkatkan Penjualan Luscious Chocolate Potato Snack. PERFORMA: Jurnal Manajemen Dan Start - Up Bisnis, 1.

[11] Morissan. (2013). Teori Komunikasi: Komunikator, Pesan, Percakapan, dan Hubungan (Interpersonal). Ghalia Indonesia.

[12] Mulawarman, A. D. N. (2017). Perilaku Pengguna Media Sosial beserta Implikasinya Ditinjau dari Perspektif Psikologi Sosial Terapan. Jurnal Buletin Psikologi, 25, 36-44.

[13] Permatasari, Riska Ardelia, H. W. (2017). Daya Tarik Kawasan Sosrowijayan, Yogyakarta Sebagai Kampung Wisata Bagi Wisatawan Mancanegara. Pengembangan Kota, 5.

[14] Pitana, I. G. dan P. G. G. (2005). Sosiologi Pariwisata Kajian Sosiologis Terhadap Struktur, System, Dan DampakDampak Pariwisata. ANDI.

[15] Prasanti, D. (2018). Penggunaan Media Komunikasi Bagi Remaja Perempuan Dalam Pencarian Informasi Kesehatan. LONTAR.

[16] Pratiwi, N. I. (2017). Penggunaan Media Video Call Dalam Teknologi Komunikasi. Ilmiah Dinamika Sosial.

[17] Prihatiningsih, W. (2017). Motif Penggunaan Media Sosial Instagram Di Kalangan Remaja. Jurnal Communication, $8,51-65$.

[18] Rachmanto, Adi, R. T. S. (2013). Sistem Informasi Akuntansi Penjualan Perusahaan Dagang. Riset Akuntansi, 3.

[19] Rahmadi, A. (2016). Tips Produktif Bermedia Sosial. PT Gramedia.

[20] Rakhmat, J. (2010). Psikologi Komunikasi. PT Remaja Rosdakarya.

[21] Septianie, A. S. (2013). Pengaruh Menonton Tayangan Sinetron Love In Paris Terhadap Perubahan Perilaku Remaja Pada Siswa Smp Negeri 4 Samarinda. Dunia Komunikasi: Universitas Mulawarman, 1.

[22] Sondak, Sandi Hesti, Rita N. Taroreh, Y. U. (2019). Faktor-Faktor Loyalitas Pegawai Di Dinas Pendidikan Daerah Provinsi Sulawesi Utara. Emba (Jurnal Riset Ekonomi, Manajemen, Bisnis Dan Akuntansi).

[23] Suryadana, M. L. dan O. V. (2015). Pengantar Pemasaran Pariwisata. Alfabet.

[24] Tasruddin, R. (2015). Strategi Promosi Periklanan Yang Efektif. Al-Khitabah, 2.

[25] Tjiptono, F. (2015). Strategi Pemasaran, Edisi 4. Andi Offset.

[26] Wandikbo, Yakob, T Tumbel, L. F. T. (2013). Pengaruh Promosi Terhadap Peningkatan Penjualan Sepeda Motor Honda Merek CBR 150cc Pada PT. Daya Adicipta Wisesa Kec. Kalawat Maumbi Kab. Minahasa Utara. Jurnal Acta Diurna Komunikasi. 
